\title{
Biochemical Characterization, Action on Macrophages, and Superoxide Anion Production of Four Basic Phospholipases $A_{2}$ from Panamanian Bothrops asper Snake Venom
}

\author{
Aristides Quintero Rueda, ${ }^{1,2,3}$ Isela González Rodríguez, ${ }^{1}$ \\ Eliane C. Arantes, ${ }^{4}$ Sulamita S. Setúbal, ${ }^{5}$ Leonardo de A. Calderon, ${ }^{5}$ \\ Juliana P. Zuliani, ${ }^{5}$ Rodrigo G. Stábeli, ${ }^{5}$ and Andreimar M. Soares ${ }^{5}$ \\ ${ }^{1}$ Departamento de Análises Clínicas, Toxicológicas e Bromatológicas, Faculdade de Ciências Farmacêuticas de Ribeirão Preto, \\ Universidade de São Paulo, FCFRP-USP, Ribeirão Preto, SP, Brazil \\ ${ }^{2}$ Departamento de Química, Facultad de Ciencias Naturales y Exactas, Universidad Autónoma de Chiriquí, UNACHI, Panama \\ ${ }^{3}$ Departamento de Laboratorio Clínico, Complejo Hospitalario Metropolitano, Caja de Seguro Social, CHM-CSS, Panama \\ ${ }^{4}$ Departamento de Física e Química, Faculdade de Ciências Farmacêuticas de Ribeirão Preto, Universidade de São Paulo, \\ FCFRP-USP, Ribeirão Preto, SP, Brazil \\ ${ }^{5}$ Centro de Estudos de Biomoléculas Aplicadas a Saúde-CEBio, Fundação Oswaldo Cruz, FIOCRUZ Rondônia e Núcleo de Saúde, \\ Universidade Federal de Rondônia, UNIR, Porto Velho, RO, Brazil
}

Correspondence should be addressed to Rodrigo G. Stábeli; stabeli@fiocruz.br and Andreimar M. Soares; andreimar@fiocruz.br

Received 10 July 2012; Accepted 13 September 2012

Academic Editor: Luis A. Ponce Soto

Copyright (C) 2013 Aristides Quintero Rueda et al. This is an open access article distributed under the Creative Commons Attribution License, which permits unrestricted use, distribution, and reproduction in any medium, provided the original work is properly cited.

Bothrops asper (Squamata: Viperidae) is the most important venomous snake in Central America, being responsible for the majority of snakebite accidents. Four basic PLA $\mathrm{S}_{2}$ (pMTX-I to -IV) were purified from crude venom by a single-step chromatography using a CM-Sepharose ion-exchange column $(1.5 \times 15 \mathrm{~cm})$. Analysis of the N-terminal sequence demonstrated that pMTX-I and III belong to the catalytically active Asp49 phospholipase $\mathrm{A}_{2}$ subclass, whereas pMTX-II and IV belong to the enzymatically inactive

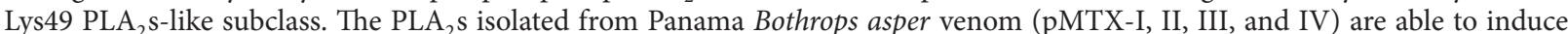
myotoxic activity, inflammatory reaction mainly leukocyte migration to the muscle, and induce J774A.1 macrophages activation to start phagocytic activity and superoxide production.

\section{Introduction}

Envenomation resulted from snakebites is the cause of considerable morbidity and mortality in many tropical and subtropical countries, being an important public health problem $[1,2]$. According to Kasturiratne et al. [2], the estimative number of deaths per year due to snakebites in 2007 for Central America ranged from 193 to 1,461. Since snakebites affect, in most cases, poor people living in rural parts of tropical countries [3], the World Health Organization (WHO), incorporated snakebite envenoming in its list of neglected diseases (http://www.who.int/neglected_diseases/ diseases/en/).

Lance-headed pit vipers belonging the Viperidae family, especially the Bothrops asper snake (Figure 1) are responsible for the most severe cases of snakebite envenoming, being the main cause of the largest numbers of bites and fatalities in Central America [1]. Among the American countries, Panama has the highest incidence of snakebite cases, showing an average number of 40 to 65 cases per 100,000 population per year and a estimated total number of 1,300 to 1,800 cases per year $[4,5]$, which B. asper is responsible for $90 \%$ of all 


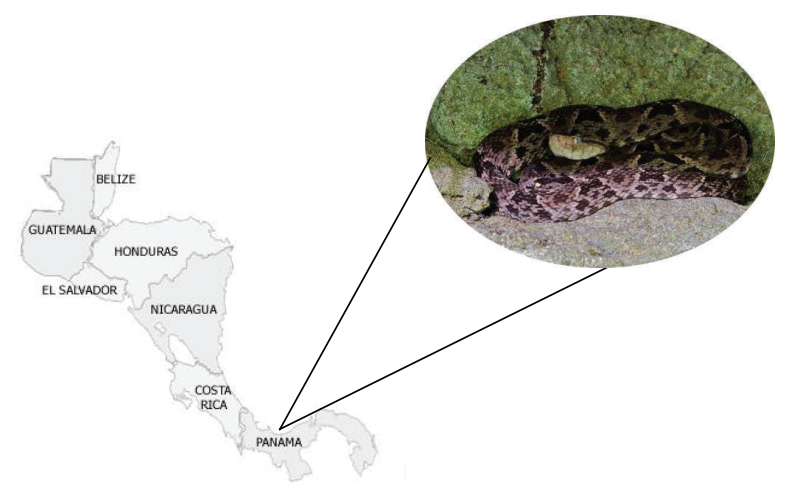

FIgURE 1: Bothrops asper resting in limestone cave, Central Panama.

snakebites cases of major clinical importance $[4,6]$. B. asper is able to inoculate a relative large amount of venom and is considered extreme aggressive, being able to cause severe accidents [7].

According to Gutiérrez et al. [5], the envenomation produced by B. asper induces prominent local tissue damage, characterized by swelling, blistering, prominent oedema, haemorrhage, dermonecrosis, and myonecrosis with clinical manifestations that include bleeding, effects on platelet aggregation, coagulopathy, hypotension, hemodynamic alterations, pulmonary oedema, and acute renal failure. Other less common effects include intravascular haemolysis, acute myocardial damage multiple organ failure, and death. The clinical features of the envenomation are affected by the venom components, which vary according to snake species, geographic region, age, sex, and environment $[5,8,9]$.

Snake venoms are characterized as a complex mixture of bioactive molecules, which proteins compose more than $90 \%$ of the venom dry weight [10-12]. Many of these proteins are enzymes, in which the most abundant are phospholipases $\mathrm{A}_{2}$ $\left(\mathrm{PLA}_{2} \mathrm{~s}\right.$; E.C.3.1.1.4) [10]. $\mathrm{PLA}_{2} \mathrm{~s}$ are members of a protein superfamily that comprise several groups of enzymes with different catalytic mechanisms, as well as different functional and structural features, that cleavage the sn-2 acyl ester bond of glycerolphospholipids producing free fatty acids and lysophospholipids $[13,14]$. Snake venom $\mathrm{PLA}_{2} \mathrm{~s}\left(\mathrm{svPLA}_{2} \mathrm{~s}\right)$ have been grouped into four classifications according to minor structural differences as group I and II, both subclassified as type A or B. The group II is found in venoms from Viperidae family, while the group I is found in Elapidae and Hydrophiidae venoms [14]. svPLA ${ }_{2}$ s from Viperidae family are placed into group IIB and are mainly subdivided in two types: Asp49 $\mathrm{PLA}_{2} \mathrm{~s}$, which have an Asp residue at position 49, and Lys49 $\mathrm{PLA}_{2} \mathrm{~s}$, showing a Lys residue at position 49. Different from Asp49 $\mathrm{PLA}_{2}$ s, Lys49 $\mathrm{PLA}_{2}$ s have low or any catalytic activity upon artificial substrates $[13,15,16]$.

This present paper describes the biochemical and toxicological characterization of crude $B$. asper venom from Panama, and the isolation, purification, and biochemical characterization of four basic cytotoxic PLA $\mathrm{PL}_{2}$ from this venom and its effects on gastrocnemius muscle and inflammation.

\section{Materials and Methods}

2.1. Materials. Bothrops asper snake venom was collected from adult specimens, captured in Caldera and Gomez (Provence of Chiriquí, Panama) and in Arraiján (Provence of Panama, Panama). The snakes were maintained in a serpentarium at the Gamboa Rainforest Resort, Panamá, where the crude venom was obtained by inducing the snake to bite a parafilm-wrapped jar. Venoms were centrifuged at $1,000 \mathrm{xg}$ for $15 \mathrm{~min}$, and supernatants were lyophilized and stored at $-20^{\circ} \mathrm{C}$ in Microbiology Department at the Medicine Faculty of Panama University until used. Male albino Swiss mice, weighing 18-22 g, were used for the assays.

The murine macrophage cell lines (J774A.1) were obtained from Rio de Janeiro Cell Bank Collection (Brazil). RPMI-1640, penicillin, streptomycin, and L-glutamine were purchased from Sigma-Aldrich (MO, USA); fetal bovine serum (FBS) was from Cultilab (Brazil). All reagents were low endotoxin or endotoxin-free grades. Animal care was in accordance with the guidelines of the Brazilian College for Animal Experimentation (COBEA) and was approved by the Committee for Ethics in Animals Utilization of Universidade de São Paulo (CEUA no. 06.1.291.53.3). CMSepharose and Phenyl-Sepharose resins were purchased from Amersham Biosciences, Uppsala, Sweden. The Kit CK-UVKinetic was purchased from Bioclin, Brazil. The following reagents: ethylenediaminetetraacetic acid (EDTA), molecular weight protein standards, and acrylamide were obtained from Sigma Chemical Co. All other chemicals reagents were of analytical grade from Merck, Aldrich or Pharmacia Biotech.

2.2. Purification and Biochemical Characterization of $P L A_{2} s$. $B$. asper crude venom $(300 \mathrm{mg})$ was dissolved in $1.5 \mathrm{~mL}$ of $0.05 \mathrm{M}$ ammonium bicarbonate buffer, $\mathrm{pH} 8.1$ and applied on a CM-Sepharose column $(1.5 \times 15 \mathrm{~cm})$ according to Soares et al. [17]. All fractions were analyzed by SDS-PAGE, and PLA 2 activity was evaluated in vitro by indirect erythrocyte lysis in agar containing human erythrocytes and egg yolk, as previously described [18], being the fraction with $\mathrm{PLA}_{2}$ activity selected. Polyacrylamide gel electrophoresis was performed in the presence of sodium dodecyl sulfate (SDS-PAGE) [19]. Isoelectric focusing was performed according to previously described. Buffalyte, $\mathrm{pH}$ range 3.0-9.0 (Pierce, IL), was used to generate the $\mathrm{pH}$ gradient. To determinate the protein concentration, the microbiuret method was used. The mol. wt of PLA $\mathrm{A}_{2}$ s was estimated by mass spectrometry (Quattro II, Micromass). A Procise-491 (Applied Biosystems) automatic sequencer was used for the $\mathrm{N}$-terminal sequencing [17]. The phenylthiohydantoin (PTH) amino acids were identified by comparing their retention times with the 20 PTH-amino acid standard mixture. The peptides obtained were compared with the sequences of other related proteins in the SWISSPROT/TrEMBL databases using the FASTA and BLAST tools.

\subsection{Biological and Pharmacological Characterization}

2.3.1. Lethality. Groups of four mice (18-22 g) were injected by IP route with various amounts of crude venom (in a 
volume of $0.1 \mathrm{~mL}$ ) eluted with $\mathrm{PBS}$, (phosphate buffered saline, $0.12 \mathrm{M} \mathrm{NaCl}, 0.04 \mathrm{M} \mathrm{Na}_{2} \mathrm{HPO}_{4}$, and $\mathrm{pH} 7.2$ ). Deaths were recorded at $1,3,6,12,24$, and 48 hours. $\mathrm{LD}_{50}$ was calculated using the Spearman-Karber method [20].

2.3.2. Edema-Inducing Activity. Groups of four male Swiss mice (18-22 g) were injected in the subplantar region with various amounts of crude venom (in a volume of $50 \mu \mathrm{L}$ ) prepared with $\mathrm{PBS}, \mathrm{pH}$ 7.2. Then, the paw increase was measured at different time intervals (30, 60, 120, and $180 \mathrm{~min}$ ), subtracting the initial paw measure (time $0 \mathrm{~h}$ ). The paw edema was measured with the aid of a low-pressure pachymeter (Mitutoyo, Japan).

2.3.3. Hemorrhage. Groups of four male Swiss mice (18-22 g) were injected by ID route in the dorsal region with various amounts of crude venom (in a volume of $50 \mu \mathrm{L}$ ) prepared in PBS, $\mathrm{pH}$ 7.2. The hemorrhagic activity of the venom was determined as follows. Different doses of venom were injected intradermally, in a volume of $0.1 \mathrm{~mL}$, into groups of four mice (18-22 g); $2 \mathrm{~h}$ later, they were sacrificed with $\mathrm{CO}_{2}$, their skin removed, and the area of the hemorrhagic spot was measured. Diameters were calculated, and the minimum hemorrhagic dose was defined as the dose of venom, which induced a lesion of $10 \mathrm{~mm}$ diameter [21].

2.3.4. Coagulant Effect. Platelet-poor plasma was obtained from rabbit citrated blood by centrifuging the plasma twice at $2,500 \mathrm{xg}$ for $15 \mathrm{~min}$ at $4^{\circ} \mathrm{C}$. Aliquots of $0.5 \mathrm{~mL}$ of plateletpoor plasma were incubated with various amounts of crude venom (dissolved in $100 \mu \mathrm{L}$ of $\mathrm{PBS}, \mathrm{pH}$ 7.2). Incubation was carried out for $5 \mathrm{~min}$ at $37^{\circ} \mathrm{C}$. Then, $0.1 \mathrm{~mL}$ of $0.25 \mathrm{M}$ $\mathrm{CaCL}_{2}$ was added to each tube, and they were checked for the formation of a clot every 30 seconds for a total period of $2 \mathrm{~h}$. All experiments were carried out in triplicate.

2.3.5. Fibrinolytic Activity. The fibrinolytic activity was measured using $0.6 \%$ bovine plasminogen-free fibrin plates [22]. For this purpose, $30 \mu \mathrm{L}$ of sample was placed on a fibrin plate, and the lysis area was measured after incubation at $37^{\circ} \mathrm{C}$ for $18 \mathrm{~h}$. PBS was used as negative control. The specific activity was calculated from a standard curve for the lysis area obtained with plasmin on the plasminogen-free fibrin plates. All experiments were carried out in triplicate.

2.3.6. $P \mathrm{LA}_{2}$ Activity. It was determined by incubating $0.5 \mathrm{~mL}$ of crude venom solution (at various amounts) with $50 \mu \mathrm{L}$ of egg yolk diluted $1: 5$ with $0.1 \mathrm{M}$ Tris, $10 \mathrm{mM} \mathrm{CaCl}_{2}$, and pH 8.5 buffer containing $1 \%$ Triton X-100. Incubations were carried out for $10 \mathrm{~min}$ at $37^{\circ} \mathrm{C}$. The liberated free fatty acids were extracted and titrated according to the method of Dole [23]. Crude venom from Bothrops asper (10 $\mu \mathrm{g})$ and PBS were used as positive and negative controls, respectively. All experiments were carried out in triplicate.

2.3.7. Myotoxic Activity. Groups of four male Swiss mice (18-22 g) were injected in the right gastrocnemius muscle with crude venom $(50 \mu \mathrm{g} / 50 \mu \mathrm{L}$ of PBS), MTXs $(50 \mu \mathrm{g} / 50 \mu \mathrm{L}$ of PBS), or PBS alone $(50 \mu \mathrm{L})$. After $3 \mathrm{~h}$, blood was collected from the tail in heparinized capillary tubes and centrifuged for plasma separation. Activity of creatine kinase (CK) was then determined using $4 \mu \mathrm{L}$ of plasma, which was incubated for $3 \mathrm{~min}$ at $37^{\circ} \mathrm{C}$ with $1.0 \mathrm{~mL}$ of the reagent according to the kinetic CK-UV protocol from Bioclin, Brazil. The activity was expressed in U/L, where one unit corresponds to the production of $1 \mathrm{mmol}$ of NADH per minute.

2.3.8. Histological Examination of Myonecrosis. Myotoxic activity was assayed on the basis of the morphologic alterations induced by IM injections of crude venom or MTXs $(50 \mu \mathrm{g})$ and negative control PBS $(50 \mu \mathrm{L})$ in the right gastrocnemius muscle of Swiss mice $(18-22 \mathrm{~g}, n=4)$. After $24 \mathrm{~h}$, the animals were euthanized with $\mathrm{CO}_{2}$, and a small section of the central region of the muscle was excised and soaked in fixing solution (10\% formaldehyde in PBS, v/v). The material was then dehydrated by increasing concentrations of ethanol and processed for inclusion in paraffin. The resulting blocks were sliced in $2.5 \mu \mathrm{m}$ thick sections, stained with $0.25 \%$ (w/v) hematoxylin-eosin and examined under a light microscope [17].

2.3.9. Cytotoxic Assay. Cell viability was measured by Trypan blue exclusion. In brief, monolayers of J774A.1 cells grown in RPMI-1640 medium with $100 \mu \mathrm{g} / \mathrm{mL}$ penicillin, $100 \mu \mathrm{g} / \mathrm{mL}$ streptomycin, and $2 \mathrm{mM} \mathrm{L-glutamine}$ were withdrawn and after counting $2 \times 10^{5}$ cells $/ 80 \mu \mathrm{L}$ were added to plastic vials and incubated with $20 \mu \mathrm{L}$ of different concentrations of pMTX-I, II, and III $(1.5,3$ and $6 \mu \mathrm{g} / \mathrm{mL})$ diluted in RPMI (control), for $1 \mathrm{~h}$ at $37^{\circ} \mathrm{C}$ in a humidified atmosphere $(5 \%$ $\mathrm{CO}_{2}$ ). Then, $20 \mu \mathrm{L} 0.1 \%$ Trypan blue was added to $100 \mu \mathrm{L}$ of J774A.1 macrophage suspension. Viable cell index was determined in a Neubauer's chamber by counting a total number of 100 cells. Results were expressed as percentage of viable cells.

2.3.10. Colorimetric NBT Assay. The colorimetric NBT assay was conducted in J744A.1 cells. In this assay, the generation of superoxide was estimated by reducing nitroblue tetrazolium (NBT), a yellow liposoluble compound that becomes insoluble and blue in its reduced form [24]. For this test, the cells J774A.1 had their concentration adjusted to $2 \times$ $10^{5} / 100 \mu \mathrm{L}$ and were incubated with $100 \mu \mathrm{L}$ of RPMI containing NBT $0.1 \%$ (control) or $100 \mu \mathrm{L}$ of $2 \times 10^{6}$ zymosan particles suspension diluted in RPMI containing NBT $0.1 \%$ (positive control) or $100 \mu \mathrm{L}$ of different concentrations of pMTX-I, II, and III $(1.5,3$ and $6 \mu \mathrm{g} / \mathrm{mL})$ diluted in RPMI containing NBT $0.1 \%$, and incubated for $1 \mathrm{~h}$ at $37^{\circ} \mathrm{C}$ in humidified atmosphere $\left(5 \% \mathrm{CO}_{2}\right)$. At the end of the incubation period, the vials were centrifugated for 30 seconds at $4,500 \mathrm{xg}$, and the cells were washed twice with warm PBS. The NBT reduced deposited inside the cells were then dissolved, first by adding $120 \mu \mathrm{L}$ of $2 \mathrm{M} \mathrm{KOH}$ to solubilize cell membranes and then by adding $140 \mu \mathrm{L}$ of DMSO to dissolve blue formazan with gentle shaking for $10 \mathrm{~min}$ at room temperature. The dissolved NBT solution was then transferred to a 96-well plate 
and absorbance was read on a microplate reader at $620 \mathrm{~nm}$. Data were expressed as absorbance.

2.3.11. Phagocytic Activity of J774A.1 Cells of Nonopsonized Zymosan. J774A.1 cells were plated on $13 \mathrm{~mm}$ diameter glass coverslips (Glass Tecnica, Brazil) in 24-well plates at a density of $2 \times 10^{5}$ cells per coverslip and allowed to attach for $2 \mathrm{~h}$ at $37^{\circ} \mathrm{C}$ under a $5 \% \mathrm{CO}_{2}$ atmosphere. Nonadherent cells were removed by washing with PBS. Cell monolayers were cultured for $1 \mathrm{~h}$ with RPMI supplemented with $100 \mu \mathrm{g} / \mathrm{mL}$ penicillin, $100 \mu \mathrm{g} / \mathrm{mL}$ streptomycin, and $2 \mathrm{mM} \mathrm{L}$-glutamine at $37^{\circ} \mathrm{C}$ and $5 \% \mathrm{CO}_{2}$, and then challenged with RPMI (control) or $6 \mu \mathrm{g} / \mathrm{mL}$ of pMTX-I, II, and III diluted in RPMI. After washing in cold PBS, the monolayers were incubated for $1 \mathrm{~h}$ at $37^{\circ} \mathrm{C}$ and $5 \% \mathrm{CO}_{2}$ with nonopsonized zymosan, prepared as described below, and unbound particles were removed by washing with PBS. Cells were fixed with $2.5 \%$ glutaraldehyde for $15 \mathrm{~min}$ at room temperature, and the coverslips were mounted in microscope slides. The extent of phagocytosis was quantified by contrast phase microscopic observation. At least 200 macrophages were counted in each determination, and those containing three or more internalized particles were considered positive for phagocytosis $[25,26]$. Results were presented as the percentage of cells positive for phagocytosis.

The zymosan particles, obtained from yeast cell walls, were suspended in PBS providing a concentration of $3 \mathrm{mg} / \mathrm{mL}$. After that, the zymosan suspension was sonicated for $15 \mathrm{~min}$, and total zymosan particles were determined in a Neubauer's chamber. The ratio of zymosan per macrophage was $1: 10$.

2.4. Statistical Analysis. Results are presented as mean \pm S.D. obtained with the indicated number of tests. The statistical significance of differences between groups was evaluated using $t$ student test. A $0.1<P<0.05$ value was considered to indicate significance.

\section{Results and Discussion}

Panamanian B. asper snake venom induced hemorrhage, edema, myonecrosis, coagulation, and fibrinolytic activities in vitro, and lethality, also presenting $\mathrm{PLA}_{2}$ activity evidenced by titrimetric and indirect hemolytic assays (Table 1). The toxicological profile was qualitatively similar to that previously described for B. asper from Costa Rica [12] and Guatemala [27]. The nature and biological properties of snake venom components are peculiar to each species [8], whereas the presence and concentration of several venom components could vary intraspecifically as a function of geographic distribution, age, sex, feeding, size, season, and the time elapsed between venom extraction $[9,11,28]$. These intraspecific variations have evident clinical and therapeutic implications and can affect the capacity of antivenoms to neutralize venoms from snakes of geographically separated populations $[5,11,13,29,30]$.

Four basic svPLA $\mathrm{A}_{2} \mathrm{~s}$ were highly purified in a single step purification using an ion-exchange chromatography performed on a CM-Sepharose column. The elution of absorbed
TABLE 1: Toxic activities induced by $B$. asper snake venom from Panama.

\begin{tabular}{|c|c|}
\hline Effect $^{a}$ & Activity \\
\hline Lethal $\left(\mathrm{LD}_{50} ; \mu \mathrm{g} / \mathrm{mouse}\right)$ & 55 \\
\hline Edema-inducing $(\mathrm{DEM} ; \mu \mathrm{g})^{\mathrm{ab}}$ & $1 \pm 0.1$ \\
\hline Hemorrhagic $(\mathrm{MHD}, \mu \mathrm{g})^{\mathrm{ab}}$ & $1.2 \pm 0.2$ \\
\hline Coagulant $(\mathrm{MCD} ; \mu \mathrm{g})^{\mathrm{ab}}$ & $3.5 \pm 0.05$ \\
\hline Fibrinolytic (MFD; $\mu \mathrm{g})$ & 0.5 \\
\hline Indirect hemolitic $(\mathrm{MHeD} ; \mu \mathrm{g})^{\mathrm{ab}}$ & $7.2 \pm 0.01$ \\
\hline Phospholipase $\mathrm{A}_{2}(\mathrm{mEq} / \mathrm{mg} \cdot \mathrm{min})^{\mathrm{ab}}$ & $27.2 \pm 0.45$ \\
\hline Myotoxic $(\mathrm{MMD}, \mu \mathrm{g})^{\mathrm{ab}}$ & $10 \pm 1$ \\
\hline
\end{tabular}

proteins with a linear gradient of concentrated buffer resulted in seven fractions (Figure 2(a)), which fractions $\mathrm{Ba}-4$ to Ba-7 were related to $\mathrm{PLA}_{2}$ s. Ba- 4 and $\mathrm{Ba}-5$ fraction were related to $\mathrm{PLA}_{2}$ enzymatically active, whereas $\mathrm{Ba}-6$ and $\mathrm{Ba}-$ 7 were related to enzymatically inactive $\mathrm{PLA}_{2}$. The purity degree of the isolated proteins was further demonstrated by SDS-PAGE, mass spectrometry, and N-terminal sequence (Figures 2 and 3 ) and named as pMTX-I, pMTX-III, pMTXIV, and pMTX-II, respectively. Different from our study, others research groups have exhaustively purified $\mathrm{PLA}_{2} \mathrm{~S}$ from Bothrops venoms using different combinations of chromatographic methods: gel filtration, ion exchange, RP-HPLC, and affinity with antibodies and heparin $[13,31]$.

The purified proteins were characterized as single polypeptide chains, with an isoelectric point ranging from 8.1 to 8.3. The average molecular mass estimated by mass spectrometry was $14,156.5$ for pMTX-I, 14,249.5 for pMTXII, and 14,253.0 for pMTX-III (Figure 3). The N-terminal sequence alignment of pMTX-I and pMTX-III with MTICR myotoxic III PLA 2 (Uniprot accession no.: P20474) from Costa Rican B. asper showed, respectively, $96 \%$ and $88 \%$ of identity, and the sequence alignment of pMTX-II and pMTX-IV showed, respectively, 96\% and 94\% of identity with $B$. asper MTIICR myotoxic IV PLA 2 (Uniprot accession no.: P24605). Additionally, multiple sequence alignment of pMTX-I, II, III, and IV with Costa Rica Bothrops PLA $_{2} \mathrm{~s}$ showed highly conserved amino acids, such as cysteine residues involved in disulfide bond formation. Several other conserved residues important to $\mathrm{PLA}_{2}$ catalytic activity, such as the catalytic site $\left(\mathrm{D}_{42} \mathrm{XCCXXHD}_{49}\right)$ and the calciumbinding site $\left(\mathrm{X}_{27} \mathrm{CGXGG}_{32}\right)[13,31]$ were shown. The $\mathrm{N}$ terminal sequences (Figure 2(b)) of the isolated MTXs demonstrated that pMTX-I and III are basic PLA $_{2}$ s with an aspartate residue at position 49 (Asp49), therefore catalytically active (Figure 4(a)), whereas MTX-II and IV are basic $\mathrm{PLA}_{2}$ s displaying a lysine residue at the same position (Lys49) (Figure 4(a)), therefore, catalytically inactive.

Panamanian B. asper crude venom, pMTX-I, II, III, and IV showed a high myotoxic activity (Figure 4(b)). Histopathological analysis revealed a drastic myonecrosis, displaying contracted and clumped fibers in different stages 


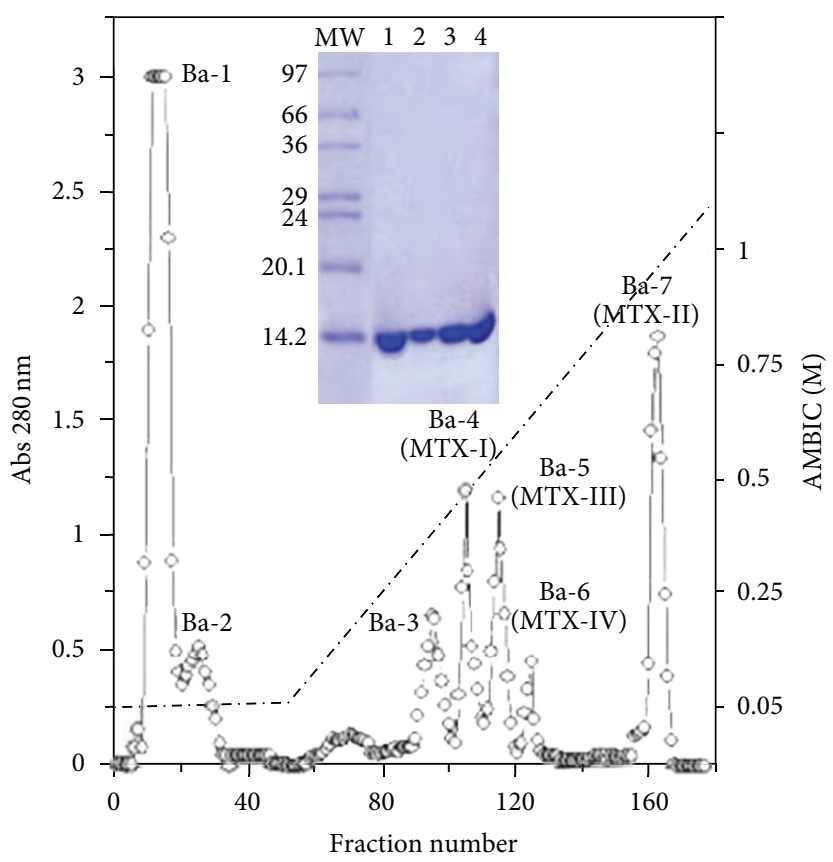

(a)

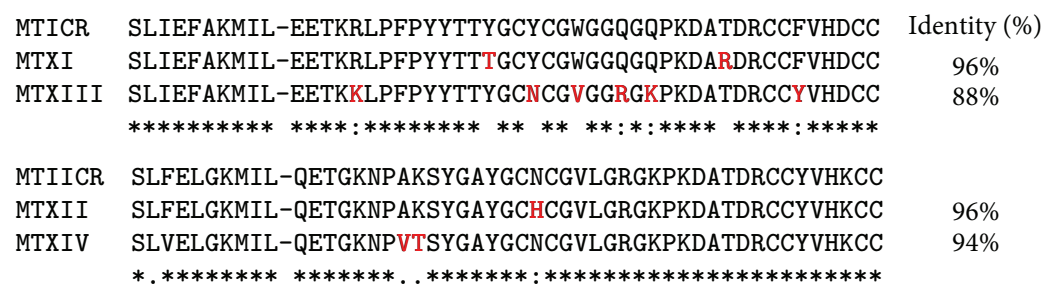

(b)

FIgURE 2: (a) Purification of myotoxins: ion exchange column of Panama B. asper venom (300 mg) on a CM-Sepharose column equilibrated with AMBIC $0.05 \mathrm{M} \mathrm{pH} 8.0$ and eluted with a concentration gradient of AMBIC up to $1 \mathrm{M}$ at a flow rate of $1.5 \mathrm{~mL} / \mathrm{minute}$. Inserted: SDS-PAGE 12\%. Samples: MW (molecular weight markers); (1) pMTX-I (20 $\mu \mathrm{g}) ;$ (2) pMTX-II (20 $\mu \mathrm{g})$; (3) pMTX-III (20 $\mu \mathrm{g})$; (4) pMTX-IV (20 $\mu \mathrm{g})$. (b) Comparison of the $\mathrm{N}$-terminal amino acid sequence of phospholipases $\mathrm{A}_{2}$ isolated from Panama $B$. asper venom: pMTX-I and III belong to the subgroup Asp49, whereas pMTX-II and IV belong to the subgroup Lys49 when compared with myotoxin III (P20474-PA21 BOTAS) Asp49 and myotoxin II (P24605-PA2H2 BOTAS) Lys49 from Costa Rica B. asper venom.

of degeneration and leukocyte infiltrate induced by myotoxins. Our results agree with Gutiérrez and Lomonte [32] and suggest that Lys49 myotoxins pMTX-II and pMTX-IV can affect the cell membrane of skeletal muscle fibers by a phospholipid hydrolysis independent mechanism. These results suggest that, moreover the catalytic site, this toxin may possess another molecular region that can bind and disorganize skeletal muscle plasma membrane $[31,32]$. Some studies have suggested that myotoxic $\mathrm{PLA}_{2}$ s may induce muscle cell damage by affecting the integrity of plasmatic membranes, thereby leading to hyper contraction and other intracellular effects $[13,31,32]$.

In order to evaluate the activation of leukocytes, the toxicity of $B$. asper myotoxins on macrophage J774A.1 cell line were studied. The cells were incubated with different concentrations of pMTX-II, III, and IV during 1 hour. These myotoxins did not affect the macrophage viability, which are in agreement with Zuliani et al. [25], showing their low toxicity on this cell type. Additionally, the effect of the same myotoxins on J774A.1 phagocytosis ability was evaluated via $\beta$-glucan receptor, by the uptake of nonopsonized zymosan particles incubated with noncytotoxic concentrations of pMTX-II, III, and IV was investigated. Our data showed that J774A.1 macrophages incubated with RPMI showed an average of phagocytosis of $16.5 \pm 0.5 \%$. Incubation of macrophages with pMTX-II, III, and IV, at $6 \mu \mathrm{g} / \mathrm{mL}$, resulted in phagocytic indexes of $30.6 \pm 0.6 \%, 29.3 \pm 5.5 \%$, and $36.5 \pm$ $2.5 \%$, respectively. These results showed that the myotoxins 

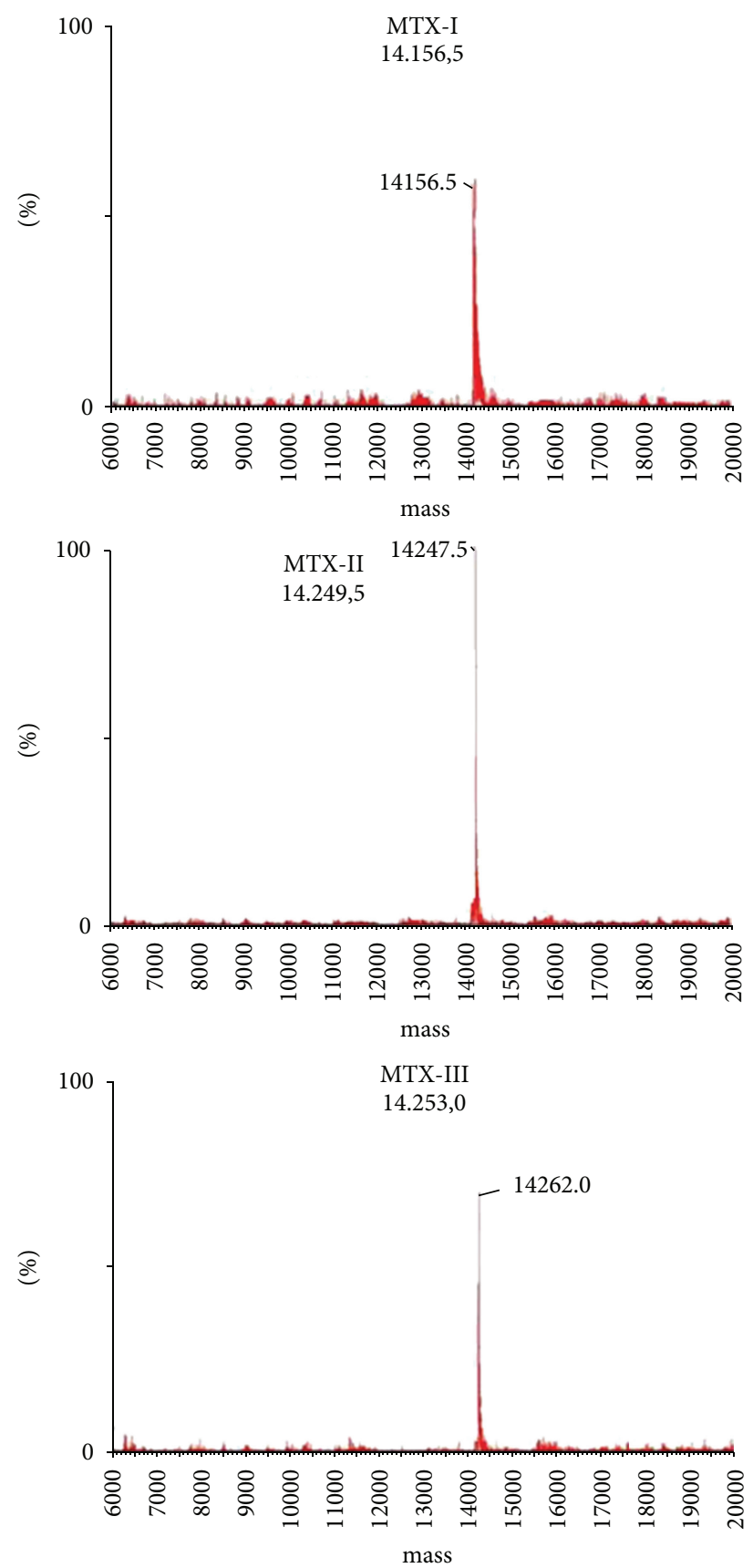

FIGURE 3: Analysis of mass spectra of $\mathrm{PLA}_{2} \mathrm{~s}$ isolated: pMTX-I, $\mathrm{Mr}=$ 14,156; pMTX-II, Mr = 14,249; pMTX-III, Mr = 14,253.

studied were able to stimulate phagocytosis of non-opsonized zymosan particles by J774A.1 macrophages (Figure 5(a)), which are in agreement with Zuliani et al. [25]. Moreover, these results suggest that phospholipid hydrolysis catalytic activity is not essential for the activity observed and argue with the hypothesis that other molecular regions distinct from the active site may be involved in this effect.

One of the most immediate responses of macrophages during phagocytosis is the production of the potent oxygen free radical, superoxide anion. The enzyme complex primarily responsible for the production of this highly reactive oxygen species is the NADPH oxidase complex [33]. This reaction parallels the release of a variety of inflammatory mediators that play crucial roles in the host defense by microbial killing, but may also cause injury to surrounding tissues [33-35]. In order to investigate the ability of pMTXII, III, and IV to induce the production of superoxide by a macrophage cell line J774A.1, the cells were incubated with non-cytotoxic concentrations of myotoxins. As shown in Figure 5(b), J774A.1 macrophages incubated with RPMI (negative control) showed a superoxide production average of $0.316 \pm 0.05$ D.O., and J774A.1 incubated with RPMI plus non-opsonized zymosan (positive control) showed a superoxide production average of $0.455 \pm 0.1$ D.O. Incubation of macrophages with pMTX-II, III, and IV, at 3 and $6 \mu \mathrm{g} / \mathrm{mL}$, respectively, induced a significant production of $\mathrm{O}_{2}{ }^{-}$in J774A.1 macrophages, showing that myotoxins are able to induce superoxide production by J774A.1 macrophages, indicating the ability of these toxins to activate these cells. Again, these results suggest that the $\mathrm{PLA}_{2}$ catalytic activity is not important in macrophage activation. Thus, in accordance with our results, increments in hydrogen peroxide $\left(\mathrm{H}_{2} \mathrm{O}_{2}\right)$, another reactive oxygen specie generated by a multicomponent enzyme system, NADPH-oxidase, have been described in thioglycollate-elicited macrophages incubated with MTXII and III from Costa Rica B. asper venom [25].

It is important to note that phagocytosis mediated by $\beta$-glucan receptors and also by mannose and $\mathrm{Fc} \gamma$ receptors are coupled to the production of both proinflammatory and microbicidal molecules, such ROS [36, 37]. Release of ROS by phagocytic cells has been implicated in microbial killing [38] as well as in the damage to host surrounding tissue [39]. Considering that MT-II and MT-III isolated from $B$. asper venom from Costa Rica display a broad cytolytic activity and affect a variety of cell types in culture [40, 41], our findings suggest the role of $\mathrm{O}_{2}{ }^{-}$in the cytotoxicity induced by these myotoxins, a hypothesis that can be addressed with the use of antioxidant agents.

In conclusion, the Panamanian B. asper venom has qualitatively a similar toxicological profile to those previously described for B. asper from Costa Rica and Guatemala despite the observation of quantitative variations in these activities. The $\mathrm{PLA}_{2} \mathrm{~s}$ isolated from Panama Bothrops asper venom (pMTX-I, pMTX-II, pMTX-III, and pMTX-IV) induced myotoxic activity, inflammatory reaction mainly leukocyte migration to the muscle, activation of macrophages to exert phagocytic activity, and production of superoxide.

\section{Conflict of Interests}

The authors declare that there is no conflict of interests.

\section{Acknowledgments}

The authors thank the financial support of Matzumae International Foundation (MIF), Japan, Organization of American States (Grantee 20050150, OAS), Instituto para la 


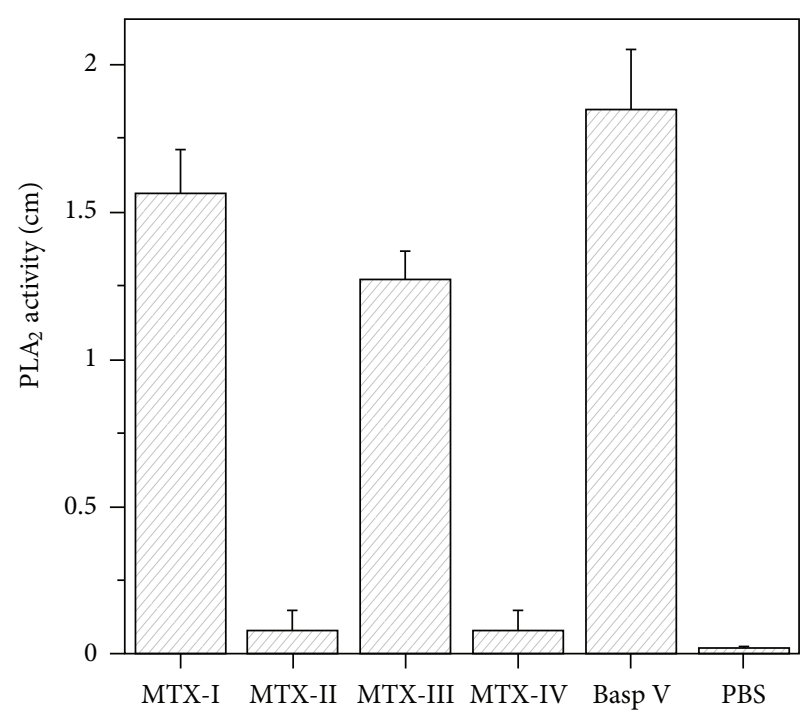

(a)

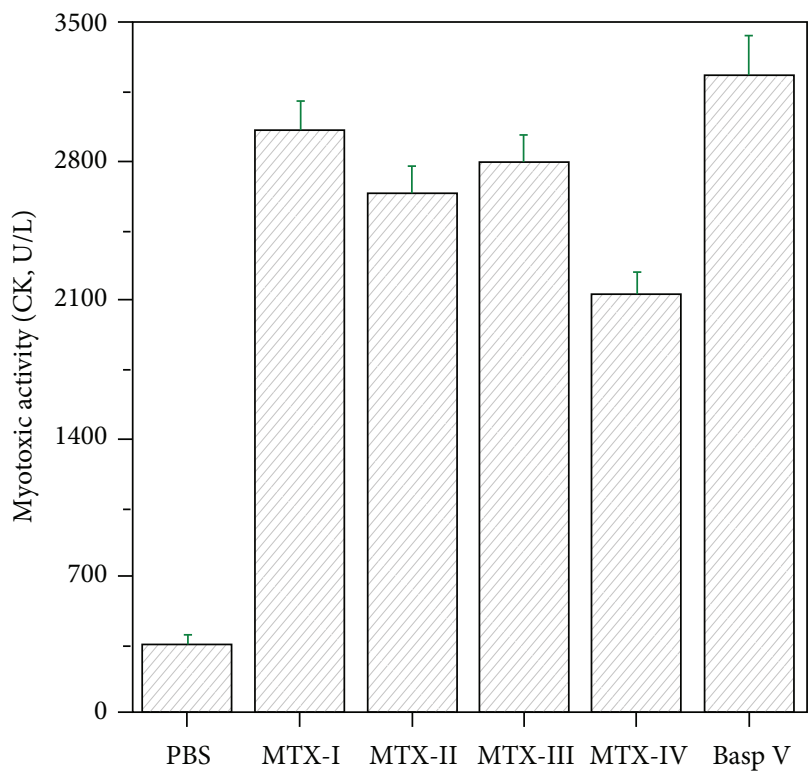

(b)

Figure 4: (a) Phospholipase activity (indirect hemolysis) of the isolated enzymes from Panama B. asper venom. Samples: pMTX-I (5 $\mu$ g); pMTX-II $(10 \mu \mathrm{g})$; pMTX-III $(5 \mu \mathrm{g})$; pMTX-IV (10 $\mu \mathrm{g})$. Negative control (PBS) and positive control (VBasp, B. asper venom, $10 \mu \mathrm{g})$; (b) myotoxic activity of the $\mathrm{PLA}_{2} \mathrm{~S}$ isolated from Panama $B$. asper venom. Swiss mice were injected with $50 \mu \mathrm{L}$ of the different samples in the right gastrocnemius muscle and, after $3 \mathrm{~h}$, the blood from the tail was collected in capillaries with heparine. Negative (PBS), positive control (BaspV, B. asper venom, $25 \mu \mathrm{g}$ ), and isolated myotoxins $(50 \mu \mathrm{g})$ were used. Values represent the mean \pm S.D. from 3 independent experiments.

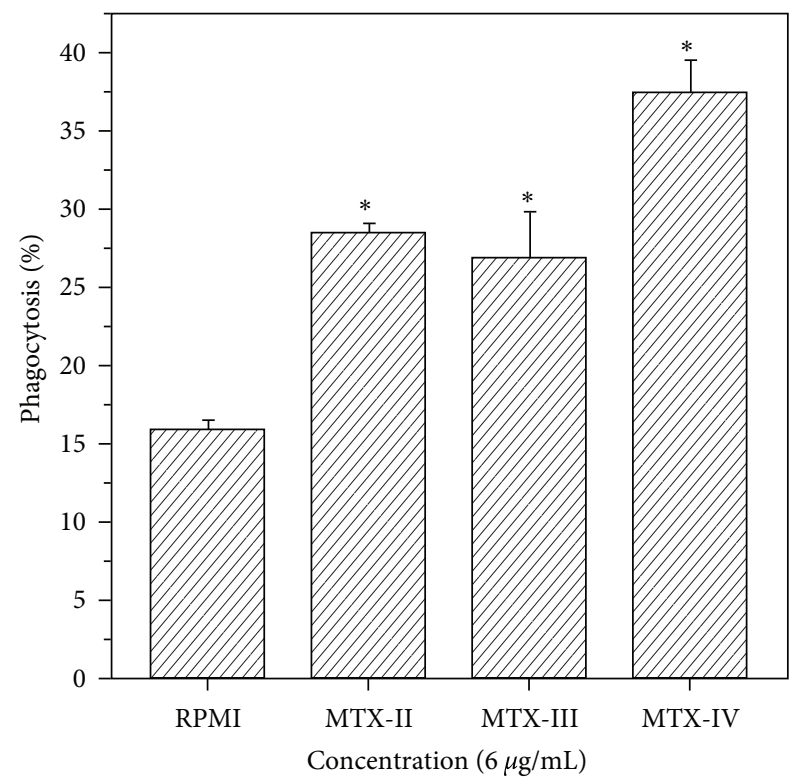

(a)

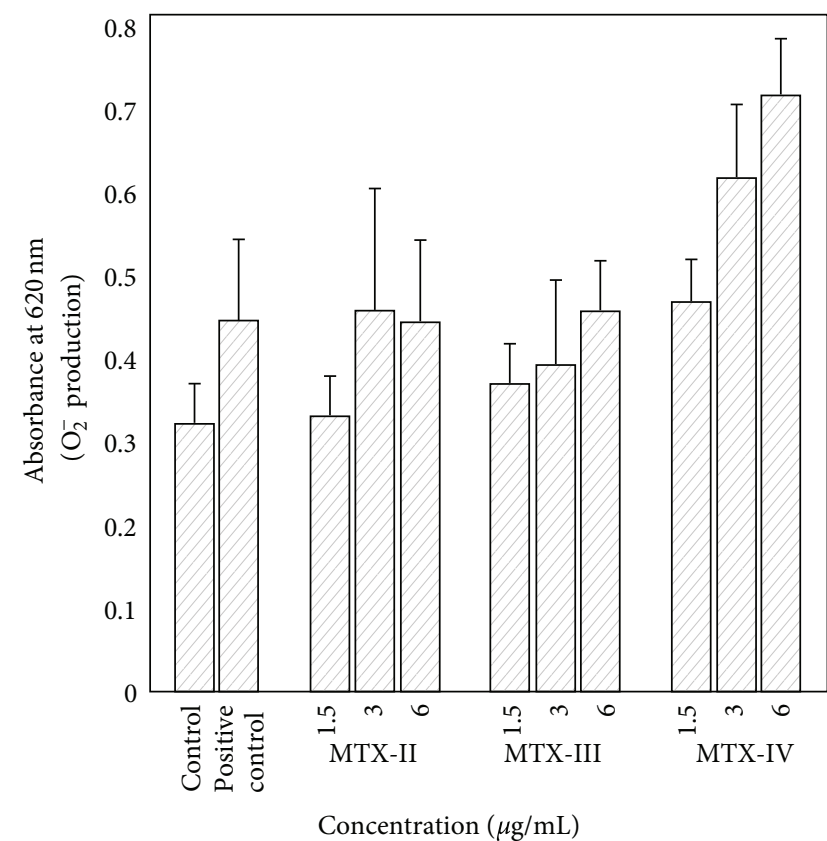

(b)

FIgURE 5: Effect of pMTX-II, pMTX-III, and pMTX-IV on phagocytosis (a) and $\mathrm{O}_{2}{ }^{-}$production (b) by J774A.1 macrophages. The phagocytosis of nonopsonized zymosan particles was determined by phase-contrast microscopy. J774A.1 macrophages were incubated with $6 \mu \mathrm{g} / \mathrm{mL}$ of pMTX-II, pMTX-III,pMTX-IV, and RPMI (control) during 60 minutes before addition of non-opsonized zymosan particles. Values represent the mean \pm S.D.M. from 3-5 independent experiments. ${ }^{*} P<0.05$ compared with control ${ }^{\#} P<0.05$ compared with positive control (ANOVA). 
Formación y Aprovechamiento de los Recursos HumanosSecretaria Nacional de Ciencia y Tecnología, (IFARHUSENACYT) Panamá, Caja de Seguro Social (CSS), Panamá, Fundação de Amparo à Pesquisa do Estado de São Paulo (FAPESP), Financiadora de Estudos e Projetos-FINEP, Coordenação de Aperfeiçoamento de Pessoal de Nível SuperiorCAPES, projeto Nanobiotec Brasil 10 e Conselho Nacional de Desenvolvimento Científico e Tecnológico (CNPq), Brazil.

\section{References}

[1] J. M. Gutiérrez, R. D. G. Theakston, and D. A. Warrell, "Confronting the neglected problem of snake bite envenoming: the need for a global partnership," PLoS Medicine, vol. 3, no. 6, pp. 0727-0731, 2006.

[2] A. Kasturiratne, A. R. Wickremasinghe, N. De Silva et al., "The global burden of snakebite: a literature analysis and modelling based on regional estimates of envenoming and deaths," PLOS Medicine, vol. 5, no. 11, pp. 1591-1604, 2008.

[3] M. Kindhauser, Communicable Diseases, 2002: Global Defense Against the Infectious Disease Threat (WHO/CDS/2003.15), WHO, Geneva, Switzerland, 2003.

[4] A. Quintero, "El envenenamiento ofIdico en Panamá: epidemiología, fisiopatología y evaluación por el Laboratorio Clínico," Tecnomédica, vol. 1, pp. 24-27, 2000.

[5] J. M. Gutiérrez, H. W. Fan, C. L. M. Silvera, and Y. Angulo, "Stability, distribution and use of antivenoms for snakebite envenomation in Latin America: report of a workshop," Toxicon, vol. 53, no. 6, pp. 625-630, 2009.

[6] D. A. Jutzy, S. H. Biber, N. W. Elton, and E. C. Lowry, "A clinical and pathological analysis of snake bites on the Panama Canal Zone.," The American Journal of Tropical Medicine and Hygiene, vol. 2, no. 1, pp. 129-141, 1953.

[7] J. L. C. Cardoso, F. O. S. França, F. H. Wen, C. M. S. Málaque, and V. Haddad, Animais Peçonhentos no Brasil: Biologia, Clínica e Terapêutica dos acidentesofídicos, Ed. Sarvier, São Paulo, Brazil, 2009.

[8] M. T. Assakura, M. De Fatima Furtado, and F. R. Mandelbaum, "Biochemical and biological differentiation of the venoms of the lancehead vipers (Bothrops atrox, Bothrops asper, Bothrops marajoensis and Bothrops moojeni)," Comparative Biochemistry and Physiology B, vol. 102, no. 4, pp. 727-732, 1992.

[9] M. L. Ferreira, A. M. Moura-Da-Silva, F. O. S. Franca, J. L. Cardoso, and I. Mota, "Toxic activities of venoms from nine Bothrops species and their correlation with lethality and necrosis," Toxicon, vol. 30, no. 12, pp. 1603-1608, 1992.

[10] D. C. I. Koh, A. Armugam, and K. Jeyaseelan, "Snake venom components and their applications in biomedicine," Cellular and Molecular Life Sciences, vol. 63, no. 24, pp. 3030-3041, 2006.

[11] J. P. Chippaux, Snake Venoms and Envenomations, Krieger Publishing Company, Florida, Fla, USA, 2006.

[12] Y. Angulo and B. Lomonte, "Biochemistry and toxicology of toxins purified from the venom of the snake Bothrops asper," Toxicon, vol. 54, no. 7, pp. 949-957, 2009.

[13] R. M. Kini, Venom Phospholipase $A_{2}$ Enzymes: Structure, Function and Mechanism, John Wiley \& Son, Chichester, UK, 1997.

[14] R. H. Schaloske and E. A. Dennis, "The phospholipase $\mathrm{A}_{2}$ superfamily and its group numbering system," Biochimica et Biophysica Acta, vol. 1761, no. 11, pp. 1246-1259, 2006.
[15] B. Lomonte, Y. Angulo, and L. Calderón, "An overview of lysine-49 phospholipase $A_{2}$ myotoxins from crotalid snake venoms and their structural determinants of myotoxic action," Toxicon, vol. 42, no. 8, pp. 885-901, 2003.

[16] C. F. P. Teixeira, E. C. T. Landucci, E. Antunes, M. Chacur, and Y. Cury, "Inflammatory effects of snake venom myotoxic phospholipases A A $_{2}$, Toxicon, vol. 42, no. 8, pp. 947-962, 2003.

[17] A. M. Soares, V. M. Rodrigues, M. I. Homsi-Brandeburgo et al., "A rapid procedure for the isolation of the LYS-49 myotoxin II from Bothrops moojeni (caissaca) venom: biochemical characterization, crystallization, myotoxic and edematogenic activity," Toxicon, vol. 36, no. 3, pp. 503-514, 1998.

[18] J. M. Gutierrez, C. Avila, E. Rojas, and L. Cerdas, "An alternative in vitro method for testing the potency of the polyvalent antivenom produced in Costa Rica," Toxicon, vol. 26, no. 4, pp. 411-413, 1988.

[19] U. K. Laemmli, "Cleavage of structural proteins during the assembly of the head of bacteriophage T4," Nature, vol. 227, no. 5259, pp. 680-685, 1970.

[20] WHO, World Health Organization Progress in the Characterization of Venoms and Standardization of Antivenoms, WHO, Geneva, Switzerland, 1981.

[21] J. M. Gutiérrez, J. A. Gené, G. Rojas, and L. Cerdas, "Neutralization of proteolytic and hemorrhagic activities of Costa Rican snake venoms by a polyvalent antivenom," Toxicon, vol. 23, no. 6, pp. 887-893, 1985.

[22] R. S. Rodrigues, L. F. M. Izidoro, S. S. Teixeira et al., "Isolation and functional characterization of a new myotoxic acidic phospholipase $\mathrm{A}_{2}$ from Bothrops pauloensis snake venom," Toxicon, vol. 50, no. 1, pp. 153-165, 2007.

[23] V. P. Dole, "A relation between non-esterified fatty acids in plasma and the metabolism of glucose.", The Journal of clinical investigation, vol. 35, no. 2, pp. 150-154, 1956.

[24] N. Madhavi and U. N. Das, "Effect of n-6 and n-3 fatty acids on the survival of vincristine sensitive and resistant human cervical carcinoma cells in vitro," Cancer Letters, vol. 84, no. 1, pp. 31-41, 1994.

[25] J. P. Zuliani, C. M. Fernandes, S. R. Zamuner, J. M. Gutiérrez, and C. F. P. Teixeira, "Inflammatory events induced by Lys-49 and Asp-49 phospholipases A 2 isolated from Bothrops asper snake venom: role of catalytic activity," Toxicon, vol. 45, no. 3 , pp. 335-346, 2005.

[26] J. P. Zuliani, J. M. Gutiérrez, L. L. Casais E Silva, S. C. Sampaio, B. Lomonte, and C. D. F. Pereira Teixeira, "Activation of cellular functions in macrophages by venom secretory Asp-49 and Lys49 phospholipases $\mathrm{A}_{2}$," Toxicon, vol. 46, no. 5, pp. 523-532, 2005.

[27] P. Saravia, E. Rojas, T. Escalante et al., "The venom of Bothrops asper from Guatemala: toxic activities and neutralization by antivenoms," Toxicon, vol. 39, no. 2-3, pp. 401-405, 2000.

[28] J. P. Chippaux, V. Williams, and J. White, "Snake venom variability: methods of study, results and interpretation," Toxicon, vol. 29, no. 11, pp. 1279-1303, 1991.

[29] A. Solórzano, Snakes of Costa Rica, Editorial INBio, San Jose, Costa Rica, 2004.

[30] A. Segura, M. Herrera, M. Villalta et al., "Venom of Bothrops asper from Mexico and Costa Rica: intraspecific variation and cross-neutralization by antivenoms," Toxicon, vol. 59, no. 1, pp. 158-162, 2012.

[31] A. M. Soares, M. R. M. Fontes, and J. R. Giglio, "Phospholipase $\mathrm{A}_{2}$ myotoxins from Bothrops snake venoms: structure-function 
relationship," Current Organic Chemistry, vol. 8, no. 17, pp. 1677-1690, 2004.

[32] J. Gutiérrez and B. Lomonte, "Phospholipase $A_{2}$ myotoxins from Bothrops snake venoms," Toxicon, vol. 33, no. 11, pp. 1405-1424, 1995.

[33] B. M. Babior, "NADPH oxidase," Current Opinion in Immunology, vol. 16, no. 1, pp. 42-47, 2004.

[34] M. Naito, "Macrophage heterogeneity in development and differentiation," Archives of Histology and Cytology, vol. 56, no. 4, pp. 331-351, 1993.

[35] H. J. Forman and M. Torres, "Reactive oxygen species and cell signaling: respiratory burst in macrophage signaling," American Journal of Respiratory and Critical Care Medicine, vol. 166, no. 12, pp. S4-S8, 2002.

[36] A. Aderem and D. M. Underhill, "Mechanisms of phagocytosis in macrophages," Annual Review of Immunology, vol. 17, pp. 593-623, 1999.

[37] J. B. Park, "Phagocytosis induces superoxide formation and apoptosis in macrophages," Experimental and Molecular Medicine, vol. 35, no. 5, pp. 325-335, 2003.

[38] X. Jiang, T. H. Wu, and R. L. Rubin, "Bridging of neutrophils to target cells by opsonized zymosan enhances the cytotoxicity of neutrophil-produced H2O2," Journal of Immunology, vol. 159, no. 5, pp. 2468-2475, 1997.

[39] R. A. Clark and S. J. Klebanoff, "Neutrophil mediated tumor cell cytotoxicity: role of the peroxidase system," Journal of Experimental Medicine, vol. 141, no. 6, pp. 1442-1447, 1975.

[40] E. Bultrón, J. M. Gutiérrez, and M. Thelestam, "Effects of Bothrops asper (terciopelo) myotoxin III, a basic phospholipase $\mathrm{A}_{2}$, on liposomes and mouse gastrocnemius muscle," Toxicon, vol. 31, no. 2, pp. 217-222, 1993.

[41] B. Lomonte, J. Lundgren, B. Johansson, and U. Bagge, "The dynamics of local tissue damage induced by Bothrops asper snake venom and myotoxin II on the mouse cremaster muscle: an intravital and electron microscopic study," Toxicon, vol. 32, no. 1, pp. 41-55, 1994. 

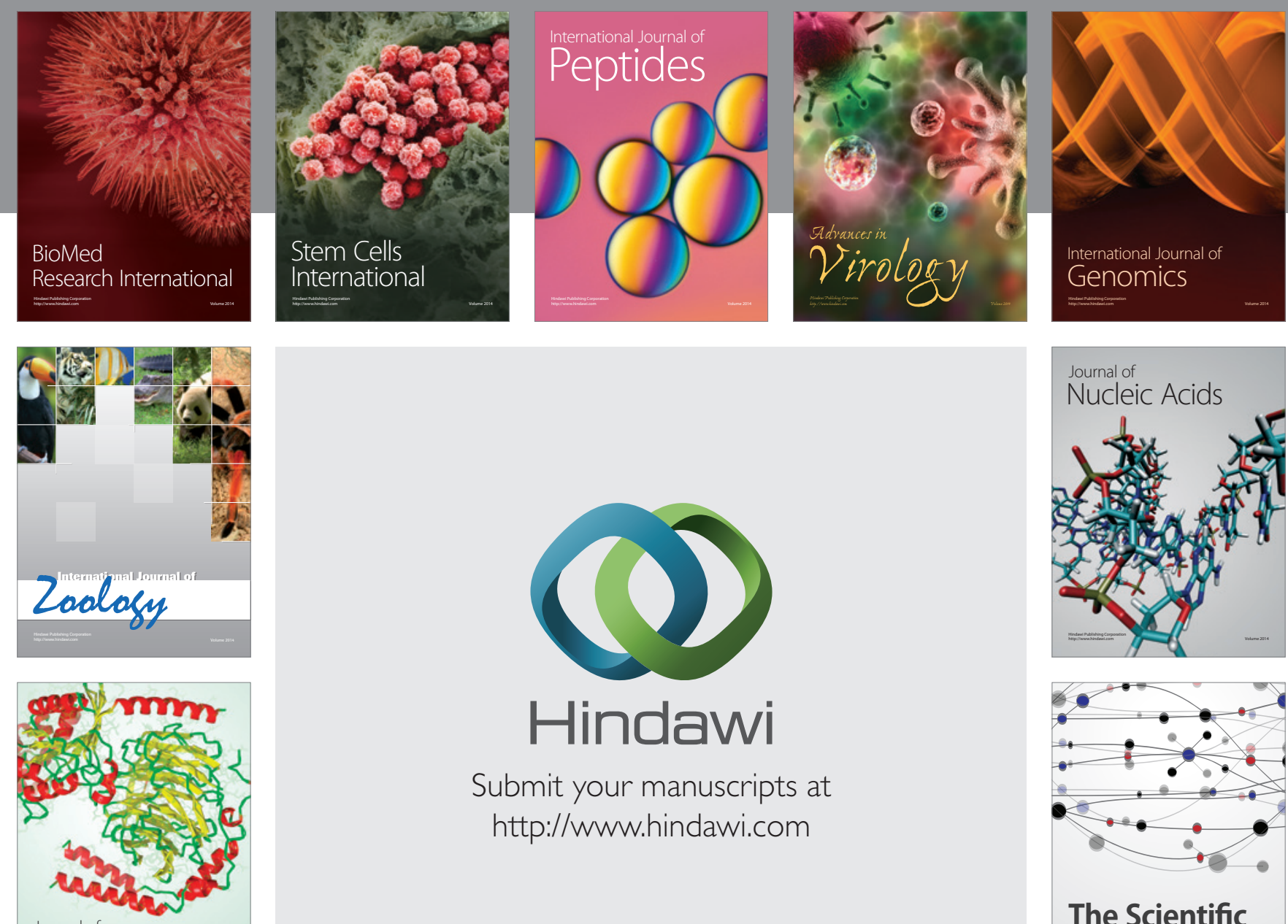

Submit your manuscripts at

http://www.hindawi.com

Journal of
Signal Transduction
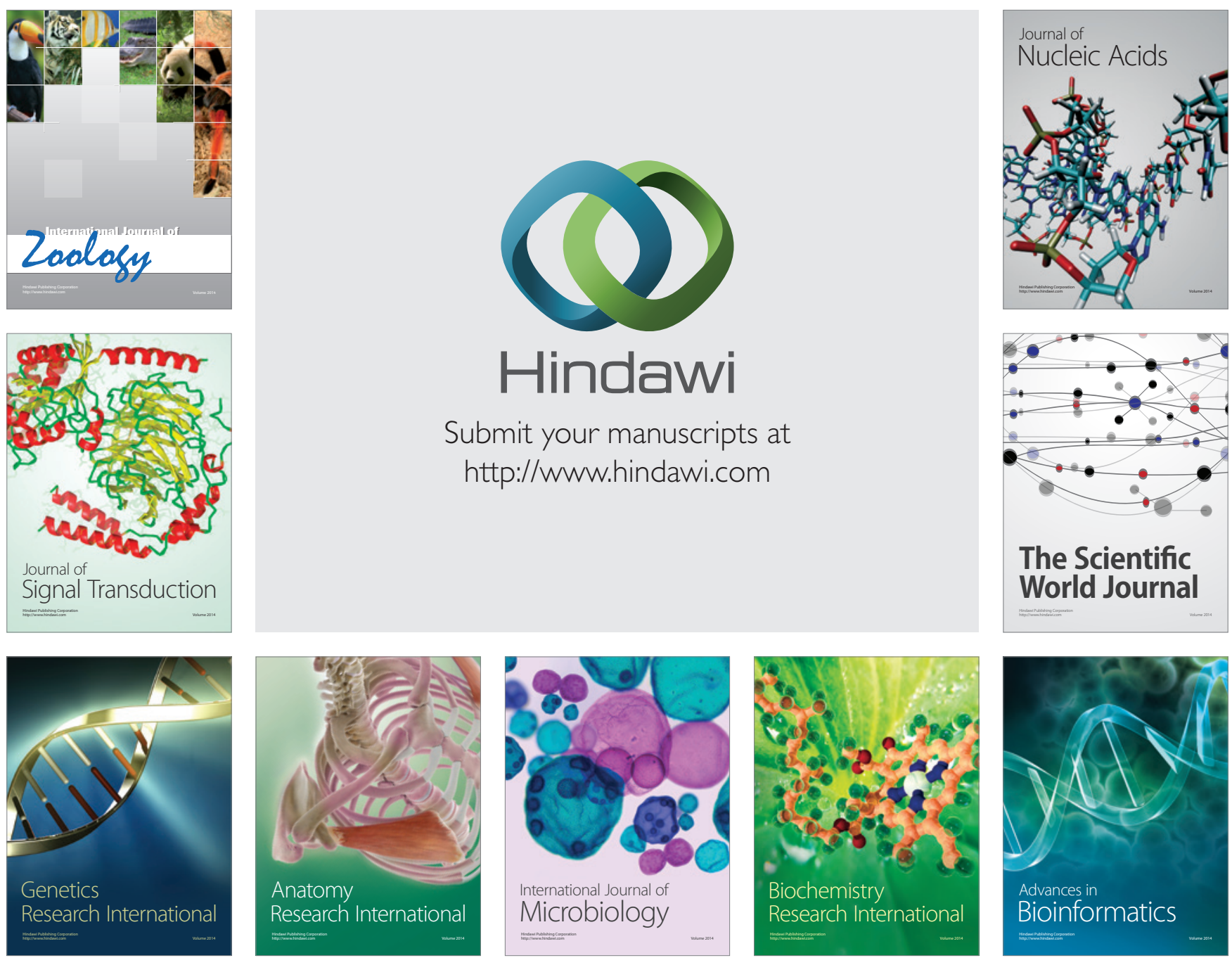

The Scientific World Journal
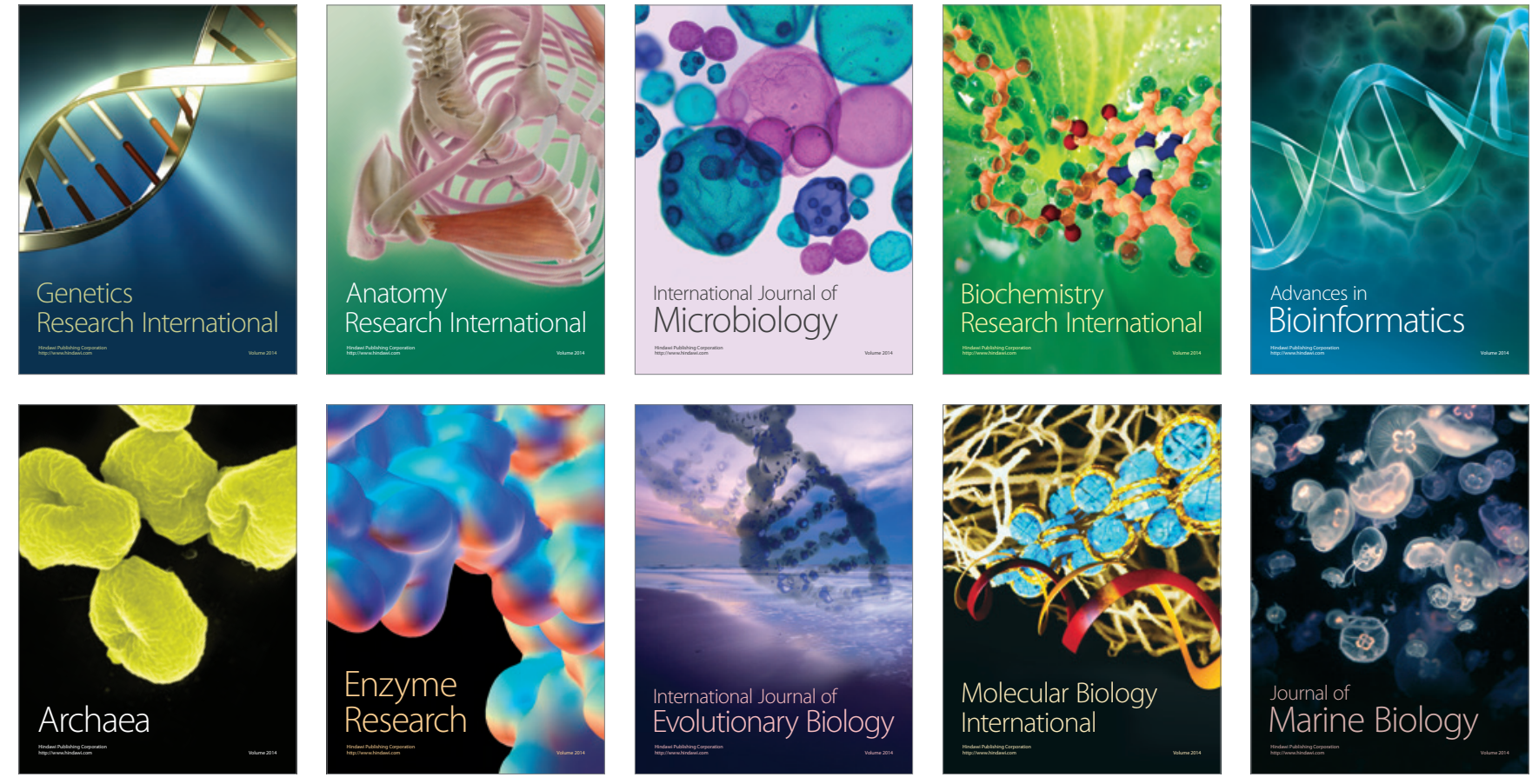